\title{
The Food Barn Role in Sustainability of Food Security (A case study on Food Barn " Lestari Boga " in the Village Muntuk, Dlingo, Bantul Indonesia)
}

\author{
Lestari Rahayu ${ }^{*}, 1$ Retno Wulandari ${ }^{2}$ and Retno Fajar Setyorini ${ }^{3}$ \\ ${ }^{1}$ Department of Agribusiness, Faculty of Agriculture \\ Muhammadiyah University of Yogyakarta \\ Email: lestari_rahayu@yahoo.com*
}

\begin{abstract}
This study aims to determine, the role of barn food in sustainability food security and the benefits obtained by the food barn. Descriptive analysis techniques used to know management of the food barn, while to know the role and benefits data analyzed using the analysis score. Results showed that the food barn role in sustainability of food security included in the high role category in the funds social grant, providing food and as economic institutions. Benefits obtained member in the presence of the food barn included in the high category, seen from the social benefits and economic benefits.
\end{abstract}

Keywords: Food barn, food security, economic benefit, social benefit

\section{INTRODUCTION}

Indonesia is an agricultural country known to have the potential of diverse natural resources. However, Indonesia is facing serious problems in terms of food shortages associated with poverty. One focus of development at this time directed at the handling of the problem of food insecurity and poverty by improving food security (Mulyono 2008).

According to Law No. 7 In 1996, food security is the fulfillment of the conditions of food for households which is reflected in the availability of adequate food, both in quantity and quality, safe, equitable and affordable. Food availability can be met from three sources: (1) the ability of domestic production; (2) food imports; and (3) management of food reserves (DKP 2006).

National food reserves consist of government food reserves managed by BULOG and community managed by the community. Traditionally people have built a system of food reserves village and household, one of them in the form of barns. Barns has been known as one of the food reserve agency in rural areas to help overcome food insecurity in times of scarcity and a disaster.
The existence of barns in the community on the wane because of government intervention to increase the role of Bulog. But Bulog is responsible for determining the price policy and the fulfillment of the national requirements have not been able to deal with food problems in Indonesia (Indonesian Ministry of Agriculture, 2010). Idea to regrow barn as food security agency that has been managed by villagers to be very important

Agricultural land in the village Muntuk is rain-fed so that during the dry season was planted corn , cassava and peanuts and is one of the villages that food insecurity has not been able to produce its own food reserves. Food Barn "Boga Lestari" in the village of Muntuk serves to maintain community food security by taking rice from outside the village Muntuk but still in the district of Bantul. Muntuk village is the village food insecurity has not been able to produce its own food reserves. Production of rice farmers just enough to meet the consumption needs of the family and even sometimes still deficient. Agricultural land in the village of rainfed Muntuk form so that during the dry season rice becomes dry and planted with corn 
, cassava and peanuts. What role for sustainable food security barns in the village of Bantul Muntuk Dlingo? What are benefits for farmers with barns?

\section{MATERIALS AND METHODS}

\subsection{Sampling Methods}

The location determination is done by purposive research in Lestari Boga Food Barn in the Village Muntuk. Technique intake of respondents using census method namely by taking all members Lestari Boga Food Barn to be the respondent . Respondents consisted of administrator barns as many as 15 peoples and members of barns as many as 30 peoples.

\subsection{Data analysis}

Food Barn Boga Lestari role to sustainability of food security and benefit food barns in the village and Muntuk analyzed by using analysis of scores.

Table 1. Indicator of the role food barn

\begin{tabular}{|c|c|c|c|}
\hline \multirow[b]{2}{*}{$\begin{array}{l}\text { Vari } \\
\text { able }\end{array}$} & \multicolumn{3}{|c|}{ Role Indicator Food barn } \\
\hline & $\begin{array}{l}\text { Channeling } \\
\text { social grands } \\
\text { funds }\end{array}$ & $\begin{array}{l}\text { the } \\
\text { provision } \\
\text { of food }\end{array}$ & $\begin{array}{l}\text { Economic } \\
\text { Institutions }\end{array}$ \\
\hline 1 & $\begin{array}{l}\text { Purchase of } \\
\text { food reserves }\end{array}$ & $\begin{array}{l}\text { Available } \\
\text { food }\end{array}$ & $\begin{array}{l}\text { Providing } \\
\text { capital }\end{array}$ \\
\hline 2 & $\begin{array}{l}\text { barns } \\
\text { Development }\end{array}$ & $\begin{array}{l}\text { Quantity } \\
\text { of food }\end{array}$ & $\begin{array}{l}\text { Production } \\
\text { facilities }\end{array}$ \\
\hline 3 & & $\begin{array}{l}\text { Quality of } \\
\text { food }\end{array}$ & $\begin{array}{l}\text { Accommoda } \\
\text { ting } \\
\text { production }\end{array}$ \\
\hline 4 & & $\begin{array}{l}\text { Food } \\
\text { safety }\end{array}$ & $\begin{array}{l}\text { Marketing of } \\
\text { production }\end{array}$ \\
\hline 5 & & $\begin{array}{l}\text { Access to } \\
\text { food and } \\
\text { affordable }\end{array}$ & \\
\hline Score & $2-6$ & $5-15$ & $4-12$ \\
\hline total & & $11-33$ & \\
\hline
\end{tabular}

To determine the role of the Food Barn Boga Lestari in the sustainability of food security in the village categorized Muntuk low, moderate and high obtained from the calculation interval Score interval =highest score-lowest score The number of categries

$$
\begin{aligned}
& =\frac{33-11}{3} \\
& =7.3
\end{aligned}
$$

Benefits barn is something that is received or perceived members of the barns where favorable or positive for the management and members of the food barn . The benefits of members and staff barns are the economic benefits and social benefits

\begin{tabular}{|c|c|c|}
\hline \multirow{2}{*}{$\begin{array}{l}\text { Vari } \\
\text { able }\end{array}$} & \multicolumn{2}{|c|}{ Benefit Indicator Food barn } \\
\hline & Economic Benefit & Social Benefit \\
\hline 1 & $\begin{array}{l}\text { Easy to get food } \\
\text { need }\end{array}$ & $\begin{array}{l}\text { Cooperative } \\
\text { relationship with } \\
\text { members }\end{array}$ \\
\hline 2 & $\begin{array}{l}\text { Utilize the barn at } \\
\text { the time of food } \\
\text { scarcity }\end{array}$ & $\begin{array}{l}\text { Cooperative } \\
\text { relationship with } \\
\text { staff }\end{array}$ \\
\hline 3 & Capital loan & $\begin{array}{l}\text { Increasing } \\
\text { knowledge }\end{array}$ \\
\hline 4 & $\begin{array}{l}\text { Sales agricultural } \\
\text { input }\end{array}$ & \\
\hline 5 & $\begin{array}{l}\text { Sales of production } \\
\text { to barn }\end{array}$ & \\
\hline 6 & Selling price & \\
\hline 7 & Purchase price & \\
\hline 8 & Interest rate loans & \\
\hline score & $8-24$ & $3-9$ \\
\hline & & \\
\hline
\end{tabular}

Table 2. Indicator Score benefit food barn

Benefit categories are divided into three categories of benefits that are not benefits, less benefit and benefit

Tabel 3. Role and Benefit of Food Barn

\begin{tabular}{|l|l|l|}
\hline Score & $\begin{array}{l}\text { Role } \\
\text { Barn }\end{array}$ & Benefit Barn \\
\hline \hline $11-18,3$ & Low & No benefit \\
\hline $18,4-25,6$ & Moderate & Less benefit \\
\hline $25,7-33$ & High & benefit \\
\hline
\end{tabular}

\section{RESULT AND DISCUSSION}

\subsection{The food barns role in the sustainability of food security}

Food barn in the village as the village community economic institutions, are useful in keeping the security of food logistics. The food barns also makes farmers have power to bargain for the price, they can choose to sell or store their production based on the prevailing price (Faridah 2014). 
Indicators of success the development of food barn are (1) output indicator: (a) use social assistance funds to purchase food reserves and strengthening institutional group (b) increased capacity in the management of barns; (2) outcome indicator: (a) the availability and development of food reserves belonging to the group on an ongoing basis, (b) Increased capacity in barn management group; (3) benefit indicator: The establishment of institutional management barn independent and sustainable society; (4) impact indicator: people's food needs are met at all times (DKP, 2010)

The food barn Boga Lestari role in the sustainability of food security is how barns capable of operating as an agency distributing social aid, community food providers and economic institution

Table 4. Role of Food Barn " Lestari Boga " in the sustainability of food security in the village Muntuk

\begin{tabular}{|l|l|}
\hline Indicators & $\begin{array}{l}\text { The } \\
\text { average } \\
\text { scores }\end{array}$ \\
\hline \hline $\begin{array}{c}\text { Channeling social grants funds } \\
\text { a. Purchase of food reserves } \\
\text { b. Barns Development }\end{array}$ & 2,49 \\
Total score & 2,13 \\
Category : Moderate & 4,62 \\
\hline The provision of food & \\
a. Available food & \\
b.Quantity of food & 3,00 \\
c. Quality of food & 2,76 \\
d.Food safety & 2,67 \\
e. Access to food and & 3,00 \\
Affordable & 3,00 \\
Total score & 14,43 \\
Category : High & \\
\hline Economic Institutions & \\
a.Providing capital & 3,00 \\
b. Production facilities & 2,60 \\
c. Accommodating & 2,49 \\
production & 2,36 \\
d. Marketing of production & 10,45 \\
Total score & 29,50 \\
\hline Category : High & \\
\hline TOTAL SCORE & \\
\hline Category : High Role & \\
\hline
\end{tabular}

Assessment from member of the barns role in the distribution of social grants is category moderate because members are not know about social grants

Assessment of the barn role as a provider of food high with score 3 . The food barn always provide food every time a food scarcity season and the harvest season. Food are provided barn also safe does not contain chemicals that are harmful. Accessing food is also very easy , each member who needs food can buy or borrow in barns at a very affordable price for the community

The barn role of food as an economic institution including the high category. Barns always provide capital at any time for members who need a loan, although loans are offered for venture capital is not much with the maximum loan Rp 500.000,-

Assessment of the barn role from members included in the high category with a score of 29.50 , indicating that the role performed by barns are already well underway. Members assess the barns has been carrying out its role in accordance with the objective being instrumental in distributing social aid, the barns can perform a role as providers of food to people, is able to perform the role as an economic institution that helps the economic problem barns member

\subsection{Benefit of food barns}

Barns instrumental in helping a group or community in the area of potential food shortages in addressing himself to get out of the problem of food shortages. Barns should be developed as an institutional rural economy in the area of food insecurity, namely: (a) barns can be an institution which provides facilities for the development of farming and agri-food such as provider of agricultural inputs, capital, information technology processing, storage and distribution and marketing of agricultural products, (b) develop independent businesses in the field of cultivation of agriculture and non-agriculture, (c) be the agency services business activities which are needed by the community, both in agriculture and non-agriculture, (d) a role in helping its members to perform partnerships with other economic institutions, (e) facilitating capacity building of its members in 
the form of skills training needed various fields of its members (Jayawinata 2003).

The barns have a very important role in supporting the availability of food in the village . Strategic benefit of the village barn is : (a) In the circumstances of crop failure due to pests and diseases or natural disasters , the needs of food filled with food reserves in the barn; (b) As a means to improve the bargaining position of farmers; (c) In the event of surplus production, farmers store their crops in the barn, and will be sold to the market on a time high price; (d) seed storage;

(e) To help meet food needs on time food scarcity.

Benefits barns is something earned or perceived members of the barns where favorable or positive for the management and members of the granary. Benefits Food barn consists from social benefits and economic benefits .

Table 5. Score benefit of food barns

\begin{tabular}{|c|c|}
\hline Indicators & $\begin{array}{l}\text { the } \\
\text { average } \\
\text { scores }\end{array}$ \\
\hline \multicolumn{2}{|l|}{ Social Benefit } \\
\hline $\begin{array}{l}\text { a. Cooperative relationship } \\
\text { with members }\end{array}$ & 2,71 \\
\hline $\begin{array}{l}\text { b. Cooperative relationship } \\
\text { with staff }\end{array}$ & 2,51 \\
\hline c. Increase knowledge & 2,35 \\
\hline Total score & 7,57 \\
\hline Category :High & \\
\hline \multicolumn{2}{|l|}{ Economic Benefit } \\
\hline a. Easy to get food need & 3,00 \\
\hline $\begin{array}{l}\text { b.Utilize the barn at the time } \\
\text { of food scarcity }\end{array}$ & 2,53 \\
\hline c.Capital loan & 2,24 \\
\hline d.Sales agricultural input & 1,89 \\
\hline e.Sales of production to barn & 2,40 \\
\hline f. Selling price & 2,22 \\
\hline g. Purchase price & 2,80 \\
\hline h. Interest rate loans & 2,64 \\
\hline Total score & 19,52 \\
\hline Category : High & \\
\hline TOTAL SCORE & 27,09 \\
\hline Category : High Benefit & \\
\hline
\end{tabular}

Barn role as a provider of food plays a role because most of the members utilizing the barn to feed during drought. Members utilizing the barns role as an economic institution to borrow capital.
Members borrow to the barn because its lending is lower than bank interest and do not require collateral to borrow money.

The selling price is the price given barns in selling goods in the barn. Agriculture input price offered in the barn by members equal to the market price so that many members who buy outside the barn because the price is the same and available at all times while in barn available only just before planting season

Benefits barns of various indicators can be categorized into the category of low benefit (score of 11 to 18.3) , the category of moderate benefit (score of $18.4-25.6$ ) and high benefit category (score of 25.7 to 33) . Table 5 shows that the benefits of the various indicators of the overall amount of the total score of 27.09. This shows the barns have high benefits for its members both social benefits and economic benefits .

\section{CONCLUSSIONS}

The number of the assessment scores barn role as the distribution of social grant funds, a provider of food and economic institution 27,09 The role of barns in the sustainability of food security can be categorized as high.

Assessment from member of benefits of the barns in the sale of agricultural inputs is still low because the sale of agricultural inputs are not available at any time. Benefits barns categorized is high, seen from the number of members assessment score that is equal to 27.27

\section{REFERENCES}

Anantanyu, S. 2011. Institutional Farmers : Role and Strategy Development Capacity. . SEPA Vol 7 No 2 : 102- 109 (Published in Indonesian)

Indonesian Ministry of Agriculture, 2010 Study of Rural Community Food Reserve System To Reduce Risk of Food insecurity $25 \%$. (Online). jurnal peran lumbung pangan.pdf accessed on 12 Mei 2014 
Faridah.2014.LumbungPangan(Online).

http://www.dompetdhuafa.net/cont ent/view/642/85/ accessed on $6^{\text {th }}$ June, 2014

Jayawinata, A. 2003. Pemberdayaan

Lumbung Pangan Masyarakat (Online). Accessed on $16^{\text {th }}$ February 2014

Mulyono, A. 2008. Study Public Participation In Village Independent Food Program Muntuk In the village of Bantul (Thesis) Master of Urban and Regional Development Techniques Graduate Program Diponegoro University . Semarang (Published in Indonesian)

Nazir. 2003. Metode Penelitian. Ghalia Indonesia. Jakarta

Rompas, F.M. 2013. Role of Food Barn Pebete Ando In the Village Independent Food Support Program in Masani village of Poso Coastal Poso distric e-Jurnal Katalogis volume I No 1 :

226-238 (Published in Indonesian) 